\title{
Håndleddsskader
}

\section{med normale røntgenfunn}

\author{
Fire av fem pasienter med normalt røntgenbilde etter en akutt hånd- \\ leddsskade hadde patologiske funn ved MR-undersøkelsen.
}

Håndleddsskader er vanlig. En del pasienter med håndleddsforstuing plages i ettertid av smerter og redusert funksjon $\mathrm{i}$ håndleddet selv om røntgenbildet viser normale funn. Ifølge gjeldende definisjon er en håndleddsforstuing en partiell leddbåndsruptur. Skafoidfraktur er det vanligste bruddet $i$ håndroten og er ofte vanskelig å diagnostisere. I dag forekommer både underdiagnostisering og overbehandling av akutte håndleddsskader der røntgenbildet var normalt.

I doktorgradsarbeidet fra Bergen legevakt fant vi at $80 \%$ av pasientene $(n=155)$ med normale røntgenbildefunn etter en akutt håndleddsskade hadde patologiske funn ved MR-undersøkelsen. Dette inkluderte 54 okkulte frakturer, 56 beinkontusjoner (bone bruises), 15 skader i triangulærbruskkomplekset og fem skafolunære ligamentskader. Vi undersøkte også treffsikkerheten av ulike kliniske tester for å diagnostisere skafoidfraktur. Vi fant at en kombinasjon av tre vanlige kliniske tester var bedre enn hver enkelt test alene. Avhandlingen omfattet også en kostnads- og nytteanalyse av ulike behandlingsstrategier ved klinisk mistanke om skafoidfraktur. Vi fant at tidlig MR-undersøkelse ikke er dyrere enn tradisjonell behandling med to ukers gipsbehandling før en ny klinisk undersøkelse.

Håndleddsforstuing er en unøyaktig diagnose. Vi foreslår at en ny definisjon av håndleddsforstuing bør være «okkult partiell eller total bløtvevs- (leddbånd, sene, muskel) eller skjelettskade etter et traume med normale røntgenbildefunn».

Torbjørn Hiis Bergh

torbjorn.bergh@k1.uib.no

\section{Nyfødtes størrelse i en multietnisk befolkning}

\author{
Mors opprinnelsesland og levekår gjennom hele livet er forbundet med \\ vekt og kroppssammensetning hos nyfødte barn.
}

Mye tyder på at det å være født liten og tynn, med mindre muskelmasse, men relativt mye fettmasse, er forbundet med økt risiko for senere å utvikle type 2-diabetes. Gjennomsnittlig fødselsvekt er lavere i flere etniske minoritetsgrupper enn i den etnisk norske befolkningen. Man vet lite om årsakene til disse forskjellene, og om dette også representerer en ulik kroppssammensetning.

I mitt doktorgradsarbeid deltok jeg i gjennomføringen av en kohortstudie av 823 gravide kvinner og deres barn. $59 \%$ hadde etnisk opprinnelse fra land utenfor VestEuropa. Rekruttering og datainnsamling ble utført ved helsestasjoner, og $74 \%$ av de inviterte deltok. Barna ble målt på barselavdelingene.

I studien viste vi at barn med etnisk opprinnelse fra land med lav økonomisk og sosial velferd hadde lavere fødselsvekt sam- menliknet med etnisk vesteuropeiske barn. Spesielt hadde de lavere ponderal indeks $\left(\mathrm{kg} / \mathrm{m}^{3}\right)$ og mindre mageomkrets. Foreldrenes størrelse og mors sosioøkonomiske status gjennom livet forklarte ikke denne «tynnheten». Effekten av mors nåværende sosioøkonomiske status på barnets fødselsvekt, lengde og mengde underhudsfett var avhengig av mors levekår tidlig i livet. Hos mødre som hadde vokst opp i familier med en lav sosioøkonomisk status, var det ingen positiv assosiasjon mellom høyere status som voksen og barnets størrelse.

Resultatene kan få betydning for oppfølging av vekst hos foster og barn og for planlegging av forebyggende tiltak mot type 2diabetes i en multietnisk befolkning.

\section{Line Sletner}

line.sletner@medisin.uio.no

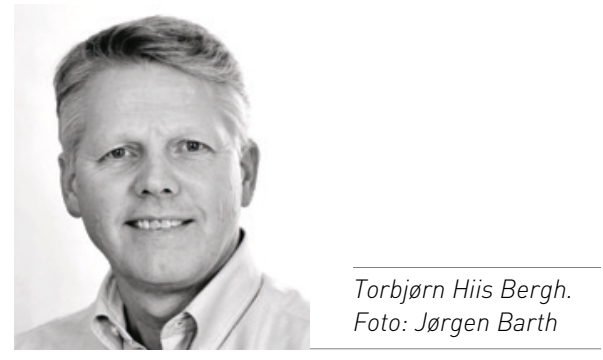

Disputas

Torbjørn Hiis Bergh disputerte for ph.d.-graden ved Universitetet i Bergen 4.4. 2014. Tittelen på avhandlingen er Wrist injuries with normal $x$-rays. A study of MRI findings, clinical tests and costs of different diagnostic strategies.

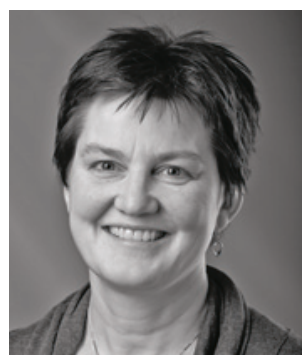

Line Sletner. Foto: $\emptyset y s t e i n$ H. Horgmo Universitetet i Oslo

Disputas

Line Sletner disputerte for ph.d.-graden ved Universitetet i Oslo 14.5.2014. Tittelen på avhandlingen er Neonatal body composition. A life course approach to ethnic and socioeconomic differences in health. 